\title{
A Monoclonal Antibody against Basal Cells of Human Epidermis Potential Use in the Diagnosis of Cervical Neoplasia
}

Vera B. Morhenn, Alain B. Schreiber, Olive Soriero, William McMillan, and Anthony C. Allison

Departments of Dermatology and Gynecology/Obstetrics, Stanford University School of Medicine, Stanford, California 94305; Institute of Biological Sciences, Syntex Research, and Syva Microbiology Syntex, Palo Alto, California 94304

\begin{abstract}
A murine monoclonal antibody was generated against human skin cells obtained from psoriatic plaques. The antibody, called VM-2, recognizes an epitope expressed on the basal cell layer of human skin and other epithelia. VM-2 also binds to cultured cells from a variety of human carcinomas including HeLa cervical carcinoma, A-431 vulvar carcinoma, A-549 lung alveolar carcinoma, and SCL-1 skin squamous cell carcinoma cells. In several primary human cell lines, including fibroblasts, endothelial cells, and cells from the hematopoietic lineage, the antigenic site recognized by VM-2 could not be detected. The cellular antigen when immunoprecipitated by VM-2 from both normal and transformed cells appears to be proteins of $\sim 100,000$ and $120,000 \mathrm{~mol}$ weight. In frozen sections from human tumor-containing tissues, VM-2 labels skin, cervical, and lung squamous carcinoma cells, as well as skin basal carcinoma cells.

Malignant cells present in exfoliative smears from epidermoid invasive neoplasias of the cervix are also selectively recognized by VM-2 in distinction to normal squamous cervical cells. VM2 is thus directed against an antigen associated with neoplastic cells when applied in selected sites of exfoliative cytology. This monoclonal antibody represents a new reagent that should prove useful in the diagnosis of cervical neoplasia.
\end{abstract}

\section{Introduction}

At present the techniques for distinguishing normal from malignant tissues and for the classification of neoplastic specimens rest mainly on the microscopic examination of cell morphology after differential staining. Histochemical and immunological criteria are sometimes used to validate the morphological observations. Recent developments in hybridoma technology have provided effective approaches to generate unlimited amounts of well-defined molecular probes for the analysis of cell surface and circulating antigens. Tumor-specific antigens recognized by monoclonal antibodies have been described for several neoplastic diseases including lymphoma (1), melanoma (2-4), and carcinoma of the ovary $(5-7)$, lung $(8,9)$, colon $(10,11)$, and breast (12). These antibodies have been successfully used as confirmatory diagnostic tools for tissue sections and in some cases for in vivo imaging of solid tumors and metastases $(2,10,12)$. Alternatively, when the antigenic molecules are shed, immunoas-

Address correspondence to Dr. Morhenn, Department of Dermatology, Stanford University School of Medicine, Stanford, CA 94305.

Received for publication 17 December 1984 and in revised form 24 June 1985.

J. Clin. Invest.

(c) The American Society for Clinical Investigation, Inc. 0021-9738/85/11/1978/06 \$1.00

Volume 76, November 1985, 1978-1983 says have been devised to measure levels in circulating blood and other biological fluids, to be correlated with tumor burden and disease progression. In the case of B cell lymphomas (1), the idiotype of the cell surface immunoglobulin is truly a tumorspecific antigen, as most, though not all (13), of these lymphomas appear to be of clonal origin (14). For most solid tumors, careful analysis of antigen specificity has often revealed either crossreactivity with fetal antigens or interindividual variations excluding the use of the antibodies as universal reagents. In other cases, quantitative rather than qualitative differences in antigen expression compared with normal tissues have been found; in these cases, tumor specificity of the antigen becomes an operational definition dependent upon assay configuration and sensitivity.

This report deals with the characterization of a monoclonal antibody to an antigen expressed at the surface of basal epidermis and other epithelia. The antibody, which is denoted VM-2, was originally generated against human skin cells derived from psoriatic plaques. VM-2 binds to an antigen expressed by a variety of squamous carcinoma cells both in tissue culture and in biopsies from human lung, cervix, and skin. Cervical carcinoma cells present in exfoliative smears bear the antigen unlike normally differentiated superficial squamous cells and other normal cell types in the same specimen. The antigen recognized by VM-2 is not tumor-specific but tumor-associated in selected sites or preparations. Therefore, we suggest that this antibody may be a useful immunodiagnostic tool in exfoliative cytology such as cervical smears.

\section{Methods}

\section{Cells}

Cells. Human foreskin fibroblasts were established from primary cultures derived from skins obtained at circumcisions; cells were used between transfers 4 to 10. Peripheral blood lymphocytes, mononuclear cells, and erythrocytes were obtained from healthy volunteers. The A-431 epidermoid vulvar carcinoma cell line, A-549 alveolar cell carcinoma cell line, and murine BALB/c 3T3 fibroblasts were obtained from Dr. G. Todaro. HeLa cervical carcinoma cells, GH3 rat pituitary tumor cells, normal rat kidney fibroblasts (NRK), Daudi (human B lymphoma), Molt (human T lymphoma), and P 388 D1 murine macrophage cell line were obtained from the American Type Culture Collection (Rockville, MD). A squamous cell carcinoma cell line (SCL-1) from human skin was obtained from Dr. N. Fusenig, Heidelberg, Germany, and bovine and rabbit aortic endothelial cells (EC) were prepared according to standard techniques. Bovine venous EC were obtained from Dr. D. Gospodarowicz (University of California at San Francisco, CA), and murine capillary EC from Dr. A. Curtis (Glasgow, Scotland). All tissue culture cells were grown in Dulbecco's minimal essential medium (DME) ${ }^{1}$ (MA Bioproducts, Walkersville, MD) containing 10\% fetal calf serum (FCS) (Hyclone).

1. Abbreviations used in this paper: DME, Dulbecco's minimal essential medium; EC, endothelial cells; ELISA, enzyme-linked immunosorbent assay. 


\section{Generation of VM-2 monoclonal antibody}

Isolation of human epidermal cells. Single cell suspensions of skin cells were prepared from split-thickness skin from psoriatic plaques removed with a keratotome (Davol, Inc., Cranston, RI) preset at 0.015 in. or from skin obtained at surgery (for keratinocyte cultures). Full-thickness skin obtained at surgery was trimmed, cut into $1 \times 5-\mathrm{cm}$ strips, and split-cut with a Castroviejo keratotome set at $0.1 \mathrm{~mm}$. Strips of split-thickness skin were treated for $25 \mathrm{~min}$ at $37^{\circ} \mathrm{C}$ with $0.3 \%$ trypsin (M. A. Bioproducts, Walkersville, $\mathrm{MD}$ ) in $0.8 \% \mathrm{NaCl}, 0.04 \% \mathrm{KCl}, 0.1 \%$ glucose, $0.084 \%$ $\mathrm{NaHCO}_{3}, \mathrm{pH} 7.3$, plus $0.1 \%$ EDTA. The skin slices were washed, transferred to complete growth medium consisting of DME plus $10 \%$ heatinactivated FCS, $50 \mu \mathrm{g} / \mathrm{ml}$ gentamicin, $2 \mathrm{mM}$ L-glutamine, $50 \mathrm{U} / \mathrm{ml}$ penicillin, and $50 \mu \mathrm{g} / \mathrm{ml}$ streptomycin, and the basal and malpighian cells were released into the medium by gentle agitation.

Immunization and hybridoma production. Using standard techniques (SP2/08A2), myeloma cells were fused with spleen cells obtained from a BALB/c (National Institutes of Health strain) mouse. To immunize and boost the mouse, keratotome sections from psoriatic plaques from two unrelated donors were incubated in trypsin/EDTA as described above. The dispersed cells were washed once with complete growth medium, resuspended in phosphate-buffered saline (PBS), and injected into the mouse intraperitoneally. The hybridoma clones were screened on frozen tissue sections prepared from both normal skin and psoriatic plaques, using the immunofluorescence technique described below.

Purification and derivatization of the VM-2 antibody. VM-2 was cloned and then subcloned twice. The last two cultures were derived from microtiter wells for which serial dilutions predicted $1 / 2$ cell per well. Cells were grown in large scale in $75-\mathrm{cm}^{2}$ tissue culture flasks for $12 \mathrm{~h}$ in the absence of FCS. Conditioned medium was precipitated with $35 \%$ saturated ammonium sulfate for $4 \mathrm{~h}$ at $4^{\circ} \mathrm{C}$. Precipitates were extensively dialyzed against PBS and yielded $10-20 \mu \mathrm{g} / \mathrm{ml}$ medium semipurified VM-2 antibody. Alternatively, $10^{7} \mathrm{VM}-2$ cells were injected intraperitoneally in pristane-treated BALB/c mice. After $10 \mathrm{~d}$, ascites fluid was collected, cleared by centrifugation, and precipitated with $20 \%$ sodium sulphate. After dialysis against $5 \mathrm{mM}$ phosphate buffer, $\mathrm{pH} 8.0$, VM-2 antibody was further purified on DEAE-Sephacel with a 5-300$\mathrm{mM}$ gradient of phosphate buffer, $\mathrm{pH}$ 8.0. The purity of the antibody was assessed by immunoelectrophoresis and sodium dodecyl sulphatepolyacrylamide gel electrophoresis (SDS-PAGE), and found to be higher than $95 \%$.

\section{Isotype Determination of $V M-2$}

Ouchterlony immunodiffusion. An aliquot of supernatant of VM-2 hybridoma cells was placed into the center well of a $2 \%$ agar plate. Monospecific rabbit anti-mouse Ig isotype antibodies (Meloy) were placed in the outer wells and the plate was incubated for $2 \mathrm{~h}$ at room temperature and overnight at $4^{\circ} \mathrm{C}$.

Flexible polyvinylchloride 96-well plates (Costar, Cambridge, MA) were coated with $0.1 \mathrm{mg} / \mathrm{ml}$ goat anti-mouse $\mathrm{Ig}$ antibodies for $2 \mathrm{~h}$ at $37^{\circ} \mathrm{C}$ and countercoated with a $3 \%$ BSA solution for $2 \mathrm{~h}$ at $37^{\circ} \mathrm{C}$. VM2 hybridoma supernatant was then incubated at $37^{\circ} \mathrm{C}$ for $2 \mathrm{~h}$. After being washed with PBS containing $0.1 \%$ BSA (PBS-BSA), plates were incubated at $37^{\circ} \mathrm{C}$ for $2 \mathrm{~h}$ with monospecific rabbit anti-mouse Ig isotype antibodies coupled to peroxidase (Zymed). After being washed, plates were incubated with $1 \mathrm{mg} / \mathrm{ml}$ orthophenylenediamine and $0.03 \% \mathrm{H}_{2} \mathrm{O}_{2}$ in $0.1 \mathrm{M}$ citrate buffer, $\mathrm{pH} 4.5$. Optical density at $630 \mathrm{~nm}$ was determined on a Dynatech enzyme-linked immunosorbent assay (ELISA) plate reader (Dynatech Co., Cambridge, MA).

\section{Cellular antibody assay}

Adherent cells were grown to subconfluence in 96-well Linbro dishes; cells growing in suspension were allowed to adhere to the 96-well dishes for $30 \mathrm{~min}$ at $37^{\circ} \mathrm{C}$ after precoating of the wells with $50 \mu \mathrm{l} /$ well of a $0.1 \%$ poly L-lysine (Miles Laboratories, Inc., Elkhart, IN) solution in PBS. Cells were then fixed in the wells for $5 \mathrm{~min}$ at room temperature with $0.25 \%$ glutaraldehyde (Sigma Chemical Co., St. Louis, MO) and washed 3 times with PBS. Dishes were either used immediately or stored at $4^{\circ} \mathrm{C}$ in humidified chambers. Cells were incubated at $37^{\circ} \mathrm{C}$ for $2 \mathrm{~h}$ with monoclonal antibody, washed with PBS-BSA, and further incubated with rabbit anti-mouse Ig antibodies coupled to peroxidase (Zymed or Cappel Laboratories, Cochranville, PA) at $37^{\circ} \mathrm{C}$ for $2 \mathrm{~h}$. After washing with PBS-BSA, the cells were incubated for $10 \mathrm{~min}$ at room temperature with $1 \mu \mathrm{g} / \mathrm{ml}$ orthophenylenediamine and $0.03 \% \mathrm{H}_{2} \mathrm{O}_{2}$ in $0.1 \mathrm{M}$ citrate buffer, $\mathrm{pH}$ 4.5. Optical density (O.D.) at $630 \mathrm{~nm}$ of individual wells was determined on a Dynatech ELISA plate reader (Dynatech). O.D. readings 10-fold higher than those of controls (no first and/or no second antibody incubation) were considered to reflect significant binding of the antibody to the cells.

Alternatively, $10^{7} \mathrm{VM}$-2-producing hybridoma cells were incubated at $37^{\circ} \mathrm{C}$ for $1 \mathrm{~d}$ with $100 \mu \mathrm{Ci}$ selenium ${ }^{75}$ methionine (New England Nuclear, Boston, MA) in methionine-deficient medium and 10\% dialyzed serum. The medium was collected and the specific activity of VM-2 was determined by competition radioimmunoassay with unlabeled VM-2 as $2,500 \mathrm{cpm} / \mathrm{ng}$ protein. Flexible polyvinylchloride dishes coated with cells as above were incubated at $37^{\circ} \mathrm{C}$ with increasing amounts of VM-2 medium for $2 \mathrm{~h}$ before washing with PBS-BSA. The cell-associated radioactivity was counted in a gamma counter.

\section{Immunoprecipitation studies}

SCL-1, A-431, HeLa cells, and primary human keratinocytes were grown to subconfluence in 100-mm tissue culture dishes in DME containing $10 \%$ FCS. Cells were incubated at $37^{\circ} \mathrm{C}$ for $4 \mathrm{~h}$ with $100 \mu \mathrm{Ci}$ $\left[{ }^{35}\right.$ S]methionine in DME deficient in methionine (Gibco, Grand Island, NY) containing $10 \%$ dialyzed FCS. Alternatively, cells were surface iodinated with $1 \mathrm{mCi} \mathrm{Na}{ }^{125}$ (New England Nuclear) by Enzymobeads (Bio-Rad Laboratories, Richmond, CA; immobilized glucose oxidase, lactoperoxidase system). Cells were washed with PBS-BSA and lysed with PBS containing 0.5\% Triton X-100 (Sigma Chemical Co.) for 30 $\mathrm{min}$ at $4^{\circ} \mathrm{C}$. Lysates were centrifuged for $4 \mathrm{~min}$ at $10,000 \mathrm{~g}$ in an Eppendorf centrifuge to remove cell nuclei and debris. Lysates were then incubated at $4^{\circ} \mathrm{C}$ for $2 \mathrm{~h}$ with either $20 \mu \mathrm{g} \mathrm{VM}-2$ antibody or $20 \mu \mathrm{g}$ normal mouse Ig (control immunoprecipitate) and antigen-antibody complexes were precipitated with $100 \mu \mathrm{g}$ goat anti-mouse Ig antibody by overnight incubation at $4^{\circ} \mathrm{C}$ and centrifugation. Immunoprecipitates were washed four times with PBS-BSA containing $1 \%$ Triton X-100 and solubilized in $20 \mu \mathrm{l} \mathrm{Laemmli} \mathrm{sample} \mathrm{buffer} \mathrm{by} \mathrm{boiling} \mathrm{for} 2 \mathrm{~min}$. Antigen analysis was performed on 5-12\% acrylamide gradient one-dimensional SDS-PAGE. Gels were run at $30 \mathrm{~mA}$ constant intensity for $6 \mathrm{~h}$, stained with Coomassie Brilliant Blue, destained, dried, and processed for autoradiography or fluorography for 1 or $2 \mathrm{~d}$. Borohydride-tritiated protein mixtures were prepared using standard techniques and were run in parallel to allow apparent molecular weight determinations.

\section{Immunohistological techniques}

Fluorescence. VM-2 antibody was coupled to fluorescein isothiocyanate by incubation at room temperature for $30 \mathrm{~min}$ in a bicarbonate buffer, pH 9.1. Excess dye was removed by Sephadex G50 chromatography. The fluorophore-to-protein ratio varied between 3 and 6 . Tissue culture cells grown on coverslips, frozen tissue sections, or cervical smears were incubated at room temperature for $30 \mathrm{~min}$ with $50 \mu \mathrm{g} / \mathrm{ml}$ of either VM2 or fluoresceinated VM-2 in DME-BSA. In the former, a second incubation with affinity-purified goat anti-mouse Ig antibodies coupled to fluorescein (Cappel Laboratories) was performed before observation with a Zeiss Universal fluorescence microscope (Carl Zeiss, Inc., Thornwood, NY). Pictures were taken with Ektachrome 400 films (Eastman Kodak Co., Rochester, NY).

Peroxidase. Tissue culture cells grown on coverslips or frozen tissue sections were fixed (acetone or formalin) and incubated at room temperature for $30 \mathrm{~min}$ with $50 \mu \mathrm{g} / \mathrm{ml} \mathrm{VM-2}$ antibody in DME-BSA. After washes, samples were incubated with goat anti-mouse Ig coupled to biotin (Tago Inc., Burlingame, CA), washed, and allowed to react with avidinperoxidase (Vector Laboratories, Burlingame, CA). Visualization was performed with diaminobenzidine (Polysciences Inc., Warrington, PA) in the presence of $\mathrm{H}_{2} \mathrm{O}_{2}$.

Gold-silver technique. Cells grown on coverslips or frozen tissue sections were incubated with $50 \mu \mathrm{g} / \mathrm{ml} \mathrm{VM-2} \mathrm{antibody,} \mathrm{fixed,} \mathrm{and} \mathrm{further}$ 
incubated with goat anti-mouse Ig coupled to colloidal gold (GAM 20, Janssen). Visualization was achieved by incubation with silver lactate for $30 \mathrm{~min}$ in the dark according to Danscher (15).

\section{Results}

We generated several monoclonal antibodies specific for human epidermal cells by fusing SP2/08A2 with the splenocytes of mice that had been immunized with skin cells obtained from psoriatic plaques. The $\mathrm{IgG}_{1}$ monoclonal antibody denoted VM-2 binds specifically to the cells in the basal layer of the epidermis and the external root sheet of hair follicles (Fig. 1). Occasionally, in some sections, the layer of cells directly above the basal layer was also stained by the antibody though only in focal areas.

After subcloning, stabilization of the VM-2 hybridoma and antibody production from ascites fluid subjected to sodium sulfate precipitation and DEAE-Sephacel fractionation, we studied the reactivity of the purified VM-2 to a variety of cells grown in tissue culture by solid-phase enzyme-linked assays and direct binding assays. The results are summarized in Table I. VM-2 binds to an antigen expressed to different degrees on human squamous carcinoma cells from skin (SCL-1), cervix (HeLa), vulva (A-431), and lung alveolar carcinoma cells (A-549). VM2 does not bind to normal fibroblasts, endothelial cells, or cells from the hematopoietic lineage from different species. The cell surface antigen to which VM-2 binds can be visualized with different immunohistological techniques as shown in Fig. 2. Indirect immunofluorescence (Fig. $2 A$ ), avidin-biotin-immunoperoxidase (Fig. $2 B$ ), and immunogold-silver (Fig. $2 C$ ) techniques all yielded satisfactory signal amplifications to apparently similar sensitivities. Fixation of cells with either acetone, ethanol, paraformaldehyde, or glutaraldehyde did not significantly affect staining.
Table I. Reactivity of VM-2 with Cells Determined by Solid Phase Enzyme-Linked Immunoassay and Direct Binding Assay

\begin{tabular}{|c|c|c|}
\hline Cell type & O.D. Range* & $\begin{array}{l}\operatorname{Max}_{\text {com }} \\
\text { (bound/10' cellsł) }\end{array}$ \\
\hline $\begin{array}{l}\text { SCL-1 skin squamous cell } \\
\text { carcinoma (human) }\end{array}$ & +++ & $12,000 \pm 2,000$ \\
\hline A-431, vulvar carcinoma (human) & ++ & $7,500 \pm 1,500$ \\
\hline $\begin{array}{l}\text { A-549, bronchial carcinoma } \\
\text { (human) }\end{array}$ & + & $3,200 \pm 800$ \\
\hline HeLa, cervical carcinoma (human) & +++ & $11,500 \pm 1,500$ \\
\hline Foreskin fibroblasts (human) & - & $800 \pm 400$ \\
\hline 3T3 fibroblasts (murine) & - & $600 \pm 300$ \\
\hline Kidney fibroblasts (rat) & - & NT \\
\hline $\begin{array}{l}\text { Peripheral blood lymphocytes } \\
\text { (human) }\end{array}$ & - & NT \\
\hline $\begin{array}{l}\text { Peripheral blood monocytes } \\
\text { (human) }\end{array}$ & - & NT \\
\hline Erythrocytes (human) & - & NT \\
\hline Molt, T lymphoma (human) & - & NT \\
\hline Daudi, B lymphoma (human) & - & NT \\
\hline P388 $\mathrm{D}_{1}$ macrophages (murine) & - & NT \\
\hline $\begin{array}{l}\text { Aortic endothelial cells (bovine } \\
\text { rabbit) }\end{array}$ & - & NT \\
\hline $\begin{array}{l}\text { Venous endothelial cells (bovine, } \\
\text { murine, human) }\end{array}$ & - & NT \\
\hline
\end{tabular}

* At $10 \mu \mathrm{g} / \mathrm{ml} \mathrm{VM-2} \mathrm{antibody,} \mathrm{solid-phase} \mathrm{enzyme-linked} \mathrm{immunoas-}$ say. + , O.D. $>10$ times background;,++ O.D. $>20$ times background; +++ , O.D. $>40$ times background. $\ddagger$ Selenium ${ }^{75}$ methionine-labeled VM-2 antibody. $\S \mathrm{NT}$, not tested.
Figure 3. Cellular antigen immunoprecipitated by VM-2 antibody. Cells were biosynthetically labeled with either $\left[{ }^{35} S\right]$ methionine, or surface labeled with ${ }^{125} \mathrm{I}$, lysed, and incubated with complexes of either VM-2 or normal mouse Ig antibody and goat anti-mouse Ig antibodies. Immune complexes were analyzed by SDS-PAGE (7-12\% gradient) under nonreducing conditions.

$A-F, \mathrm{~A}-431$ cells: $A$, sample of total lysate $\left[{ }^{35}\right.$ S]methionine-labeled cells; $B$, sample of total lysate ${ }^{125} \mathrm{I}$ lactoperoxidase-labeled cells. $C$, ${ }^{35} \mathrm{~S}$, control normal mouse Ig immunoprecipitate; $D,{ }^{35} \mathrm{~S}, \mathrm{VM}-2$ precipitate; $E,{ }^{125} \mathrm{I}, \mathrm{VM}-2$ precipitate; and $F,{ }^{125}$ I, control normal mouse Ig immunoprecipitate.

$G-J$, keratinocytes: $G,{ }^{35} S$, control normal mouse Ig immunoprecipitate; $H,{ }^{125} \mathrm{I}$, control normal mouse Ig immunoprecipitate; $I,{ }^{35} \mathrm{~S}$, VM-2 precipitate; and $J,{ }^{125} \mathrm{I}$, VM-2 precipitate. Numbers on the side refer to molecular weight standards.

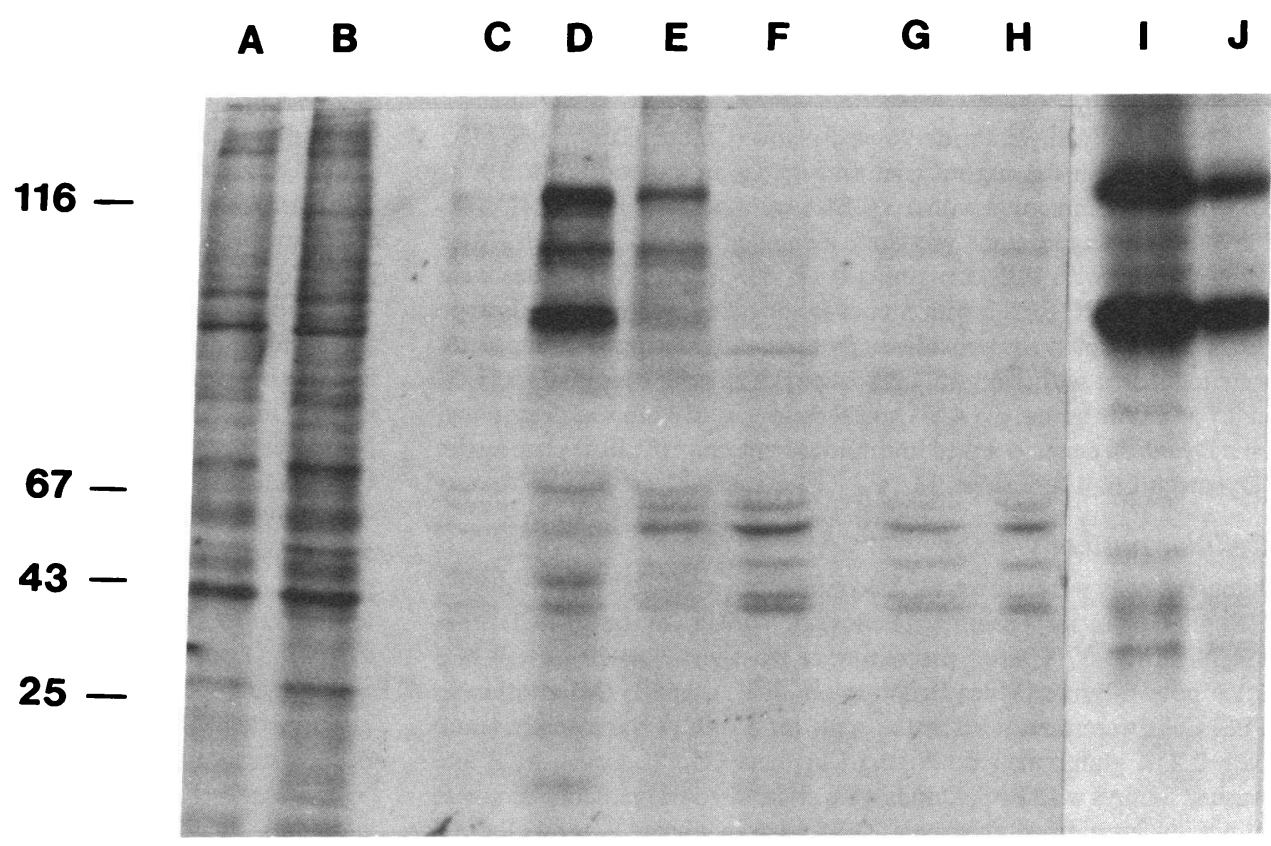




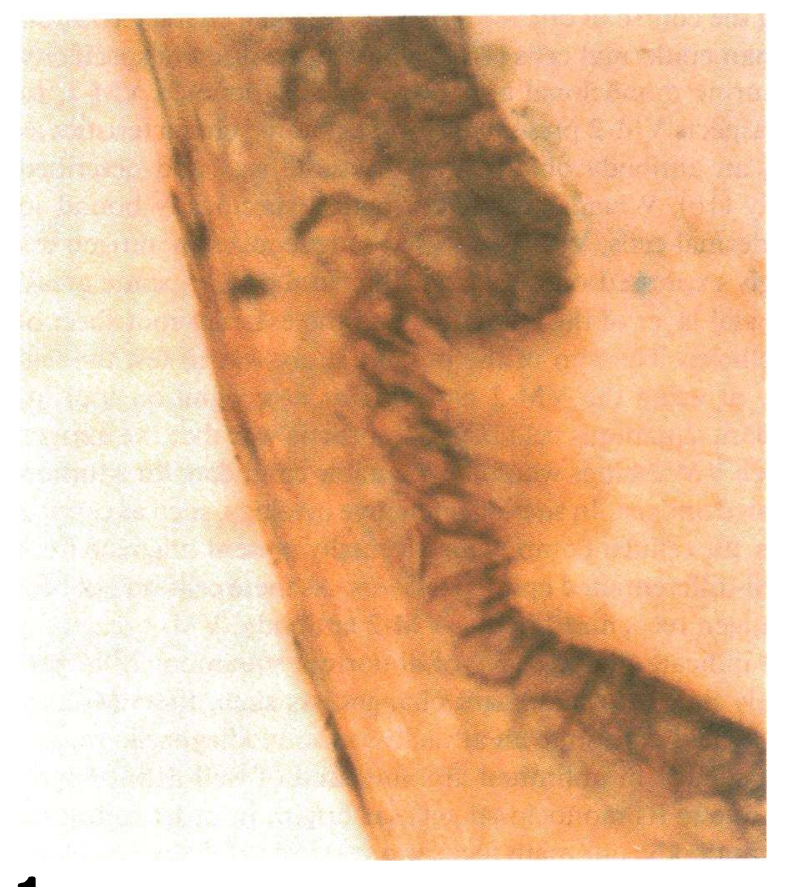

1

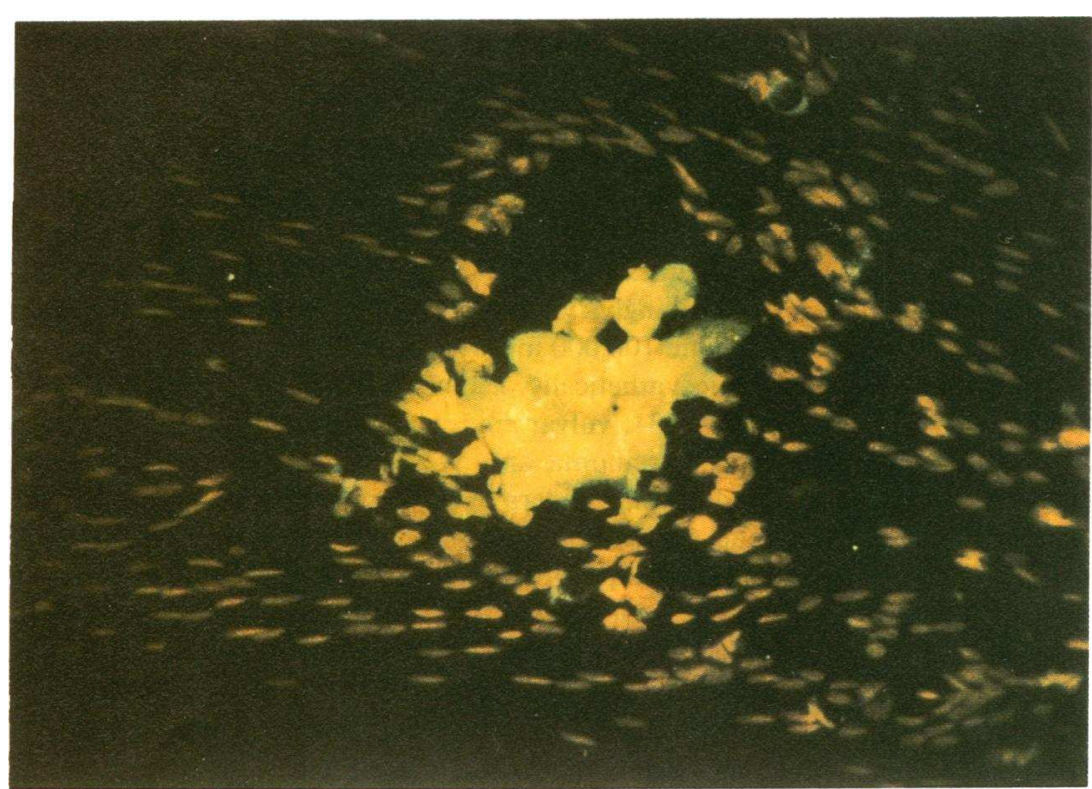

4
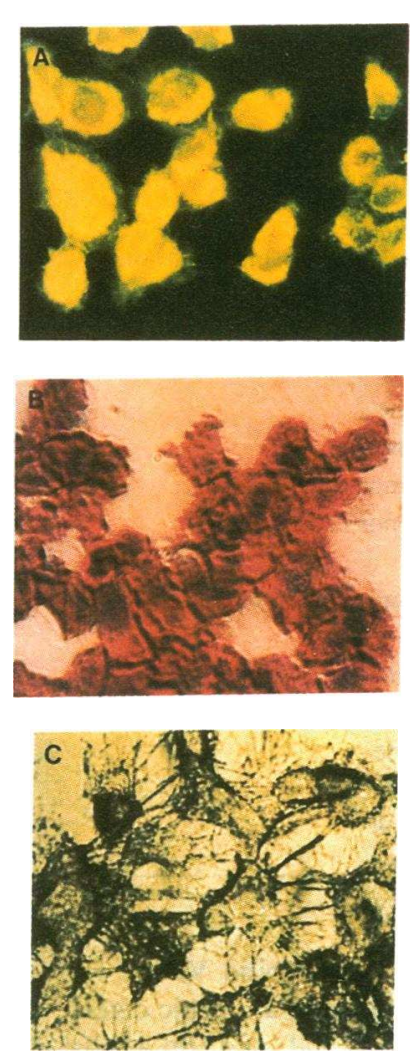

2

Figure 1. VM-2 staining of human skin. A frozen section of normal human skin obtained from a punch biopsy was incubated with $50 \mu \mathrm{g} / \mathrm{ml} \mathrm{VM-2}$ antibody. Visualization was obtained by the biotinavidin peroxidase technique as described in Methods. Note the discrete surface staining of the basal cell layer of the epidermis. Magnification, $\times 630$. Figure 2. VM-2 staining of A-431, epidermoid carcinoma cells. Cells grown on glass coverslips were incubated with $50 \mu \mathrm{g} / \mathrm{ml} \mathrm{VM-2}$ antibody for $30 \mathrm{~min}$ at room temperature, washed, fixed with paraformaldehyde, and incubated with goat anti-mouse Ig antibodies coupled either to fluorescein $(A)$, peroxidase $(B)$, or colloidal gold $(C)$. In $(B)$, visualization was achieved with diaminobenzidine in the presence of $\mathrm{H}_{2} \mathrm{O}_{2}$ and in $(C)$, with silver lactate as described in Methods.

Reactivity of VM-2 on tissue sections from cervical carcinoma biopsy. Frozen sections were incubated with $50 \mu \mathrm{g} / \mathrm{ml} \mathrm{VM-2}$ antibody followed by either biotin-avidin-peroxidase technique $(D)$ as described in Methods or fluoresceinated second antibodies $(E)$. In $(D)$, the clear border between stained tissue and normal cervical tissue. Magnification, $\times 400$.

Figure 4. Staining of malignant cells in cervical smear by VM-2 antibody. $50 \mu \mathrm{g} / \mathrm{ml}$ fluoresceinated VM-2 was incubated onto the acetone-fixed smear. Magnification, $\times 400$. 
Table II. Reactivity of VM-2 Antibody to

Normal and Neoplastic Human Tissues

\begin{tabular}{lcl}
\hline Tissue & Number & VM-2 Reactivity \\
\hline Normal skin & 8 & $\begin{array}{l}\text { + Basal cells of epidermis and } \\
\text { hair follicles }\end{array}$ \\
Lung & 2 & - None \\
Spleen & 1 & - None \\
Cervix & 4 & + Basal cells of epithelium; only \\
& & weak staining \\
Kidney & 1 & + Glomeruli \\
Trachea & 1 & + Basal cells of epithelium only \\
Liver & 1 & - None \\
Duodenum & 1 & + Basal cells of epithelium only \\
Brain cortex & 2 & - None \\
Ovary & 1 & - None \\
Cardiac muscle & 1 & - None \\
Cervix carcinoma & 22 & + Tumor cells stained \\
Lung squamous & 6 & + Tumor cells stained \\
$\quad$ carcinoma & & \\
Skin squamous & 7 & + Tumor cells stained \\
$\quad$ carcinoma & & \\
Skin basal cell carcinoma & 4 & + Tumor cells stained \\
Colon adenocarcinoma & 2 & - None \\
Prostate carcinoma & 1 & - None \\
Breast carcinoma & 2 & - None \\
Bladder carcinoma & 1 & - None \\
\hline
\end{tabular}

Having identified tissue culture cells that bind VM-2, we wished to analyze the nature of the recognized antigenic determinant. Normal epidermal cells, A-431, SCL-1, and HeLa cells were either biosynthetically labeled with $\left[{ }^{35} \mathrm{~S}\right]$ methionine or their membrane proteins iodinated by the lactoperoxidase technique. After detergent solubilization the lysates were incubated with VM-2 antibody. Analysis of the immunoprecipitates by SDSPAGE is shown in Fig. 3. A major doublet band at $120,000 \mathrm{~mol}$ $w t$ and a band at $100,000 \mathrm{~mol}$ wt appear to be specifically immunoprecipitated. Bands of similar molecular weight were obtained from the different positive cell types.

The reactivities of the VM-2 antibody with normal human tissues and biopsies of clinically and pathologically confirmed carcinomas were tested by fluorescence and peroxidase techniques. Results are listed in Table II. Except for some staining of the basement membrane in the kidney glomeruli and the basal cells of trachea and duodenum, VM-2 does not bind to normal parenchymatous cells of human tissues including lung, kidney, liver, and brain cortex. All biopsies studied were positively stained by VM-2 with high specificity as can be seen in Figs. $2 D$ and $E$. The VM-2 antibody did not react with adenocarcinoma of the colon and prostate nor with breast and bladder carcinoma biopsies.

We then wished to study whether the VM-2 antibody would identify malignant squamous cells in cervical smears. Cells on 85 cervical smears from normal volunteers were not stained by the VM-2 antibody. In contrast, 34 out of 34 smears (duplicates of smears diagnosed as malignant carcinomas by Papanicolaou staining and tissue biopsies) contained cells brightly stained by VM-2. An example of the staining is shown in Fig. 4. For some slides, coordinates of positive cells were recorded, slides were counterstained with Papanicolaou staining, and observed. The positive cells also appeared abnormal by nuclear texture, nucleolar structure, and nucleus-cytoplasmic ratio criteria. In samples with either moderate or severe dysplasia as observed by the Papanicolaou staining, the VM-2 antibody stained dysplastic cells in 19 out of 21 and 12 out of 12 samples, respectively. For this limited sampling the VM-2 reaction would have an overall sensitivity and specificity of $97 \%$.

\section{Discussion}

During the course of our work on the antigenic characterization of human epidermal cells (16), we noted the discrete specificity of a murine monoclonal antibody, which is denoted VM-2. In many aspects VM-2 presented similar staining characteristics as VM-1, an antibody obtained in the same way and described recently (16). Whereas many antibodies specifically bound to all epidermal cells, VM-2 appeared to recognize an antigen exclusively expressed on cells from the basal and, in some areas, suprabasal layer of the epidermis and the external root sheet of hair follicles. The aim of the present study was to test the feasibility of using the VM-2 antibody as a recognition tool for malignant squamous cells. Our hypothesis was that the antigen to which VM-2 binds would be a suitable candidate for a tumorassociated antigen. In sites of exfoliative cytology, such as cervical smears, the cellular components normally present originate from the well-differentiated epithelial layers. As these cells do not bear the antigen recognized by the VM-2 antibody, VM-2 reactivity would indicate the presence of abnormal squamous cells, presumably linked to malignant changes. As such, the VM-2 antibody would constitute an attractive immunodiagnostic reagent both available in unlimited amounts and of well-defined specificity due to its monoclonal cellular origin. In order to test the VM-2 antibody, our main focus was cervical exfoliative cytology, since $95 \%$ of all cervical carcinomas are of squamous origin (17). Malignant diseases of the skin, which sometimes require the identification of residual cancer cells after microscopically controlled surgery, for example, would be logical extensions in the evaluation of VM-2.

The cellular antigen for the VM-2 antibody is presumably a differentiation marker rather than tissue-specific since it is expressed by a variety of squamous carcinoma cells both in tissue culture cell lines and in tissue sections, including skin, lung, and cervix. Strikingly, proteins with similar molecular weight $(120,000$ and $100,000 \mathrm{~mol} \mathrm{wt})$ are immunoprecipitated by VM2 from biosynthetically or membrane-radiolabeled cells as different as A-431, vulvar epidermoid carcinoma, HeLa, cervical squamous carcinoma and SCL-1, skin squamous carcinoma cells, and normal epidermal cells. Current pulse-chase and peptide map studies should resolve the relationship between the various immunoprecipitated proteins. The antigen reactivity for VM-2 resists cell fixation by classical means and various assay configurations have been successfully applied using fluorescence, peroxidase, or colloidal gold-silver endpoint signals. These immunohistological techniques are easy, rapid, and yield unequivocal read-outs to the observer.

Cancer immunodiagnostics have so far been limited by the elusive nature of tumor-specific antigens. An additional problem is that although tumor cells are presumably monoclonal in origin, phenotypic and antigenic heterogeneity is usually rapidly reached. This phenomenon has been well documented both in animal experimental models (18) and human pathology (19, 20). At present, we cannot evaluate to what extent interindividual 
differences or tumor cell heterogeneity will influence the expression of the differentiation antigen recognized by the VM-2 antibody. So far 22 out of 22 biopsies of cervical carcinomas in situ and 34 out of 34 cervical carcinomatous exfoliative smears were positively identified by VM-2 immunohistological techniques.

Conventional cervical cytology is currently based on Papanicolaou staining (21-24). This widely used screening technology, almost unchanged since its inception $30 \mathrm{yr}$ ago, has resulted in a dramatic improvement in life expectancy for cervical cancer patients (25-27), thanks to early diagnosis. False positivity and false negativity rates are unfortunately rather high and vary between cancers. We do not yet know to what extent the antigen recognized by the VM-2 antibody is present on dysplastic cervical cells, the premalignant precursors for invasive cervical cancer. Preliminary results on some samples containing cells with either moderate or severe dysplasia seem to indicate that these cells will be recognized by the VM-2 antibody. Studies of many clinically well-documented specimens, tested in parallel by cytology and immunocytology, will be required to determine the antibody's widespread usefulness. These are objectives of our present efforts.

\section{Acknowledgments}

We wish to thank Eva A. Pfendt and R. Cohn for expert technical assistance.

\section{References}

1. Miller, R. A., D. G. Maloney, R. Warnke, and R. Levy. 1982. Treatment of B-cell lymphoma with monoclonal anti-idiotype antibody. N. Engl. J. Med. 306:517-522.

2. Larson, S. M., J. A. Carrasquillo, K. A. Krahn, J. P. Brown, R. W. McGuffin, J. M. Ferens, M. M. Graham, L. D. Hill, P. L. Beaumier, K. E. Hellström, and I. Hellström. 1983. Localization of ${ }^{131}$ I-labeled p97-specific Fab fragments in human melanoma as a basis for radiotherapy. J. Clin. Invest. 72:2101-2114.

3. Hellström, I., J. P. Brown, and K. E. Hellström. 1982. Workshop on monoclonal antibodies to human melanoma-associated antigens: findings of the Seattle group. Hybridoma. 1:399-402.

4. Ng, A.-K., P. Giacomini, R. Kantor, and S. Ferrone. 1982. Molecular heterogeneity and shedding of a high-molecular-mass melanomaassociated antigen identified with monoclonal antibodies. Clinical Chem. 28:2347-2350.

5. Bast, R. C., Jr., T. L. Klug, E. St. John, E. Jenison, J. M. Miloff, H. Lazarus, R. S. Berkowitz, T. Leavitt, T. Griffiths, L. Parker, V. R. Zurawski, Jr., and R. C. Knapp. 1983. A radioimmunoassay using a monoclonal antibody to monitor the course of epithelial ovarian cancer. N. Engl. J. Med. 309:883-887.

6. Mattes, M. J., C. Cordon-Cardo, J. L. Lewis, Jr., L. J. Old, and K. O. Lloyd. 1984. Cell surface antigens of human ovarian and endometrial carcinoma defined by mouse monoclonal antibodies. Proc. Natl. Acad. Sci. USA. 81:568-572.

7. Bhattacharya, M., S. K. Chatterjee, J. J. Barlow, and H. Fuji. 1982. Monoclonal antibodies recognizing tumor-associated antigen of human ovarian mucinous cystadenocarcinomas. Cancer Res. 42:16501654.
8. Brenner, B. G., S. Jothy, J. Shuster, and A. Fuks. 1982. Monoclonal antibodies to lung tumor antigens demonstrated by immunofluorescence and immunoprecipitation. Cancer Res. 42:3187-3192.

9. Mazauric, T., K. F. Mitchell, G. J. Letchworth, III, H. Koprowski, and Z. Steplewski. 1982. Monoclonal antibody-defined human lung cell surface protein antigens. Cancer Res. 42:150-154.

10. Mach, J.-P., S. Carrel, and M. Foreni. 1980. Tumor localization of radiolabeled antibodies against CEA in patients with carcinoma. $N$. Engl. J. Med. 303:5-10.

11. Accolla, R. S., S. Carrel, and J. P. Mach. 1980. Monoclonal antibodies specific for CEA and produced by two hybrid cell lines. Proc. Natl. Acad. Sci. USA. 77:563-566.

12. Rainsbury, R. M., R. J. Ott, J. H. Westwood, T. S. Kalirai, R. C. Coombes, V. R. McCready, A. M. Neville, and J.-C. Gazet. 1983. Location of metastatic breast carcinoma by a monoclonal antibody chelate labeled with indium-111. Lancet. II:934-938.

13. Sklar, J., M. L. Cleary, K. Thielemans, J. Grelow, R. Warnke, and R. Levy. 1984. Biclonal B cell lymphoma. N. Engl. J. Med. 311: 20-27.

14. Levy, R., R. Warnke, R. F. Dorfman, and J. Haimovich. 1977. The monoclonality of human B cell lymphomas. J. Exp. Med. 145: 1014-1028.

15. Danscher, G. 1981. Localization of gold in biological tissue. A photochemical method for light and electron microscopy. Histochemistry. 71:81-90.

16. Oseroff, A. R., E. A. Pfendt, L. DiCicco, and V. B. Morhenn. 1985. A murine monoclonal antibody (VM-1) against human basal cells inhibits the growth of human keratinocytes in culture. J. Invest. Dermatol. 84:257-261.

17. Christopherson, W. M., and L. A. Gray, Sr. 1982. Dysplasia and preclinical carcinoma of the uterine cervix: diagnosis and management. Semin. Oncol. 9:265-279.

18. Fidler, I. J., and R. Hart. 1982. Biological diversity in metastatic neoplasms: origins and implications. Science (Wash. DC). 217:998-1003.

19. Poste, G. 1982. Cellular heterogeneity in malignant neoplasms and the therapy of metastases. Ann. NY Acad. Sci. 397:34-48.

20. Lloyd, K. O. 1983. Basic and Clinical Tumor Immunology. Vol. 1. R. B. Herberman, editor. Nijholl, Boston, MA. 159-214.

21. Riolton, G., W. M. Christopherson, and R. Lunt. 1973. International Histological Classification of Tumors: Cytology of the Female Genital Tract. World Health Organization, Geneva.

22. Poulsen, H. E., and C. W. Taylor. 1975. International Histological Classification of Tumors. International Histological Typing of Female Genital Tract Tumors. World Health Organization, Geneva.

23. Patten, S. F., Jr. 1969. Diagnostic Cytology of the Uterine Cervix. Williams \& Wilkins Co., Baltimore, MD.

24. Patten, S. F., Jr. 1983. Female Genital Tract Diseases of the Uterine Cervix. In Manual of Cytotechnology. C. M. Keebler and J. V. Reagan, editors. American Society of Clinical Pathologists Press, Chicago, IL. 95-116.

25. Clarke, E. A., and T. W. Anderson. 1974. Does screening by "PAP" smears help prevent cervical cancer? Cancer. 34:2018-27.

26. Yajima, A., T. Mori, S. Sato, T. Wakisaka, and M. Suzuki. 1982. Effect of cytologic screening on the detection of cervical carcinoma. $\mathrm{Ob}$ stet. Gynecol. 59:565-68.

27. La Vecchia, C., S. Franceschi, A. De Carli, M. Fasoli, A. Gentile, and G. Tognoni. 1984. "PAP" smear and the risk of cervical neoplasia: quantitative estimates from a case-control study. Lancet. II:779-782. 